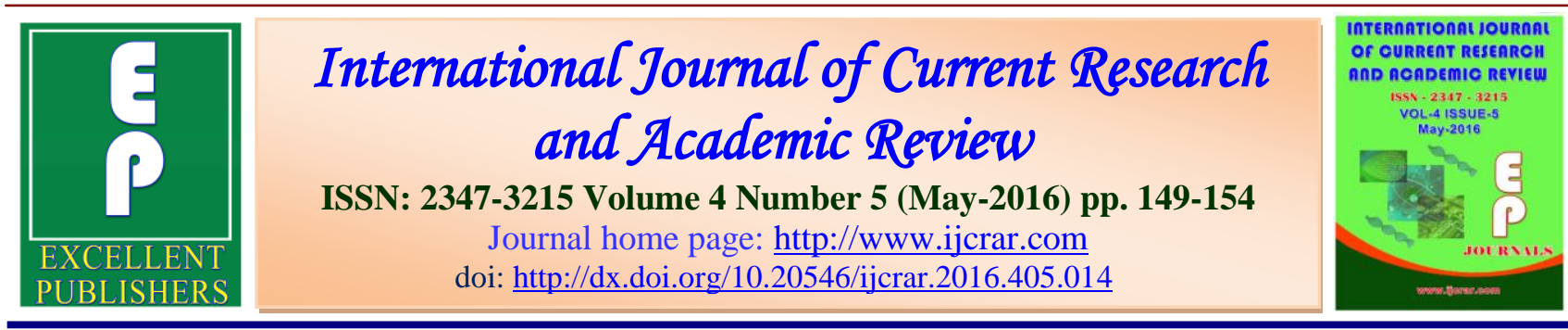

\title{
Measuring the Accumulation of Copper and Cadmium in the Vegetative Parts of the Plant and the Root of Malva parviflora as a result of Irrigation with Sewage in City of Kirkuk
}

\author{
Yasin M. Ahmed, Awaz B. Mahmood and Hiyam J. Ibrahim* \\ Department of Biology, College of Science, University of Tikrit, Iraq \\ *Corresponding author
}

\begin{tabular}{|c|c|}
\hline KEYWORDS & $A B S T R A C T$ \\
\hline $\begin{array}{l}\text { Copper, } \\
\text { Cadmium, } \\
\text { Malva parviflora, } \\
\text { Sewage, } \\
\text { accumulation of } \\
\text { Copper and } \\
\text { Cadmium. }\end{array}$ & $\begin{array}{l}\text { Included the current study, the collection of samples from the Malva } \\
\text { parviflora and water samples from regions that use wastewater for } \\
\text { irrigation and compare them with samples from the plant chard } \\
\text { irrigated arable for irrigation water was measured racial accumulation } \\
\text { of copper and cadmium in water and partial shoot and root to Malva } \\
\text { parviflora and the results show that water for irrigation sewage loaded } \\
\text { with heavy metals lead to the accumulation of elements in the parts of } \\
\text { the plant more than it is in control of the site. }\end{array}$ \\
\hline
\end{tabular}

\section{Introduction}

Sewage is one of the environment pollution factors that should be collected in a sanitary way, refined and again bring back to water cycle in nature (Abbasi, 2013). The risk assessment started to determine strategies priorities and AHP method for the reuse of wastewater. The research was conducted in the city of Hamedan by using the method of AHP and by determining criteria and a questionnaire completed by experts; shows the use of wastewater for irrigating forest had the first priority. (Reyahi Khoram et al., 2007). Assessment should be done as combined in the risk assessment of wastewater for agricultural irrigation using AHP method concluded that treated wastewater because of Benefits such as reducing limited water resources and reduce environmental pollution is considered and used in agricultural sector. But there are dangers, such as heavy metals, salts, nitrates, and their effect on human and plant that created limitation for the use of it this study showed that the risk is obtained by multiplying the risk index in effects index and by determining the amount of risks, dangers are identified (Alavi et al., 2012).

A toxic heavy metal is any relatively dense metal or metalloid that is noted for its potential toxicity, especially in environmental contexts The term has 
particular application to cadmium, mercury, lead and arsenic all of which appear in the World Health Organisation's list of 10 chemicals of major public concern. (Balasubramanian et al., 2009)

Malva parviflora is an annual or perennial herb that is native to Northern Africa, Europe and Asia and is widely naturalised elsewhere, Common names include cheesewee, $M$. parviflora leaf extracts possess anti-inflammatory and antioxidant activities. (Bouriche et al., 2011)

Malva parviflora is an exotic annual weed that is dynamic after autumn and winter rains. It is an erect, sprawling or decumbent herb growing up to $50 \mathrm{~cm}$ high that is covered with rather stiff star-like (stellate) hairs and is woody at the base (Harden, 2002)

\section{Methods and Materials}

This study is done in Kirkuk city along Qasa stream. Four polluted sites are chosen. They are polluted by sewage and solid waste. Sewage is being pumped into Qasa stream by houses randomly, or connected with passage rain water and there are a lot of $M$. parviflora. Moreover, this study conducted by taking samples of water of those areas, as well as chosen plant. Two heavy elements were being measured in water and plant. These elements are $\mathrm{Cu}$ and $\mathrm{Cd}$. For two seasons analyses were done.

\section{Measurement of Heavy Metals in the Water}

Copper $\mathrm{Cu}$ was measurable in the water depending on your company HANA Kit with a Roman-making and included a working method:

- Spectro photometer calibration device.
- fill your pipeline Blachtbar with $10 \mathrm{ml}$ of the sample checked and reset the device in this sample

- The powder was added HI 93702 OBicinchoninate close the tube and shake that the powder dissolves.

- Develop pipeline in HANA Photometer device close the tube and shake that the powder dissolves.

- Set the tube in photometer device and put pressure on the timer button and is calculated by 40 seconds and is then read the amount of copper in the water

Cadmium Cd Was measured depending on your company WTW Kit with a Germanmaking mode of action included the following:

-Measurement of $\mathrm{pH}$ and sample $\mathrm{PH}$ Must be between 3 and 11 in the event that a $\mathrm{pH}$ below or above the limit we calibrate.

- Add $5 \mathrm{ml}$ of the sample into a test tube for equipped by the company and close tube and shake well.

- Add $0.02 \mathrm{ml}$ of $\mathrm{N}, \mathrm{N}$ dimethlfomomide using a pipette, closing the crater.

- Add a teaspoon of powder thiourea close the tube that melted the powder and then wait two minutes, Develop a cell in the private company WTW Spectrophotometer device is measured by the proportion of cadmium in the water.

Measurement of Heavy Metals in the Plant

After collecting samples, dried and milled powder is digested vegetation wet digestion or acid digestion process called wet washing. (Al-Janabi et al., 1992) 
- Develop a certain weight (1-5 grams) of the sample to be digested in the Griffin beaker cup size $250 \mathrm{ml}$ is then added to it 3 $\mathrm{ml}$ of nitric acid Center then cover the cup with a bottle-hour watch glass was heating the Pacific on an electric hot plate heater.

- raise the temperature gradually to complete the digestion process and when the mixture up to near drought leave the cup cools

- Add another $3 \mathrm{ml}$ of nitric acid and the center cover of the cup and continue heating process until the end of the digestive process which is known to obtain a mixture of clear colored light-colored and so-called light colored digestate.

- The evaporation until near drought and add $5 \mathrm{ml}$ of hydrochloric acid solution with water (1:1) and are in the process heating to melt the remaining sample after digestion, then add distilled water, deionized deionized distilled water.

- The nomination for the disposal of any material is dissolved

- adjust the size of the solution were as expected concentration in the samples to the size of $100 \mathrm{ml}$ or $50 \mathrm{ml}$ or less and thus became the sample ready for analysis by atomic absorption spectrometry.

\section{Results and Discussion}

Table 1 shows the racial concentration of cadmium and copper in the water in the spring season of copper is increasing its focus in household wastewater and sewage for being included in the installation of pipelines and pots concentration of heavy metals in water-contaminated areas and have copper second higher concentration element in water as it was the highest concentration at the first site in the spring $(1.48 \mathrm{mg} / \mathrm{l})$ and the lowest concentration was in control (0.04 mg / 1) of either cadmium were less focused than copper, Sam element is having negative effects on biological processes and physiological plant of the most important influence in the work enzymes and works to change in the composition of the enzyme and inhibits its effectiveness and cause the events of mutations and cause disease cancerous to humans, and in our study of the element cadmium in water was in the spring in the first position $(0.499 \mathrm{mg} / \mathrm{l})$ and the lowest concentration was in control $(0.01$ $\mathrm{mg} / \mathrm{l}$ ) and the result of analysis Statistical show a significant difference between the sites at the level of significance $0.05<\mathrm{p}$.

Table.1 Element cadmium and copper concentration in the water

\begin{tabular}{|c|c|c|}
\hline \multicolumn{2}{|c|}{ Spring } & \multirow{2}{*}{$\begin{aligned} \text { Season } \\
\text { Element }\end{aligned}$} \\
\hline $\begin{array}{r}\text { Copper } \\
\mathrm{Mg} / \mathrm{I}\end{array}$ & $\begin{array}{l}\text { Cadmium } \\
\mathrm{Mg} / \mathrm{I}\end{array}$ & \\
\hline & & Location \\
\hline $\begin{array}{c}1.48 \\
a\end{array}$ & $\begin{array}{c}0.499 \\
a\end{array}$ & 1 \\
\hline $\begin{array}{c}0.3 \\
b\end{array}$ & $\begin{array}{c}0.48 \\
a\end{array}$ & 2 \\
\hline $\begin{array}{c}0.21 \\
b\end{array}$ & $\begin{array}{c}0.105 \\
b\end{array}$ & 3 \\
\hline $\begin{array}{c}0.04 \\
c\end{array}$ & $\begin{array}{c}0.02 \\
b\end{array}$ & control \\
\hline 0.506 & 0.276 & $\begin{array}{l}\text { Medium } \\
\text { Season }\end{array}$ \\
\hline
\end{tabular}


Int.J.Curr.Res.Aca.Rev.2016; 4(5): 149-154

Table.2 Element cadmium and copper concentration in the plant

\begin{tabular}{|c|c|c|c|c|}
\hline \multicolumn{4}{|c|}{ Spring } & \multirow{3}{*}{\begin{tabular}{|r|} 
Season \\
Element \\
part \\
\end{tabular}} \\
\hline \multicolumn{2}{|c|}{$\begin{array}{c}\text { Copper } \\
\mathrm{Mg} / \mathrm{I}\end{array}$} & \multicolumn{2}{|c|}{$\begin{array}{l}\text { Cadmium } \\
\mathrm{Mg} / \mathrm{I}\end{array}$} & \\
\hline \multirow[t]{2}{*}{ Root } & \multirow[t]{2}{*}{ Shoot } & \multirow[t]{2}{*}{ Root } & \multirow[t]{2}{*}{ Shoot } & \\
\hline & & & & Location \\
\hline 0.76 & 1.4 & 0.05 & 0.04 & 1 \\
\hline a & $a$ & $a$ & $a$ & \\
\hline 0.7 & 0.3 & 0.03 & 0.015 & 2 \\
\hline$a$ & $\mathrm{~b}$ & $a$ & $a$ & \\
\hline 0.11 & 0.17 & 0.01 & 0.01 & 3 \\
\hline c & c & $a$ & $a$ & \\
\hline 0.56 & 1.2 & 0.0 & 0.0 & contr \\
\hline $\mathrm{b}$ & $a$ & $\mathrm{~b}$ & $\mathrm{~b}$ & ol \\
\hline 0.532 & 0.7675 & 0.022 & 0.0162 & $\begin{array}{c}\text { Medium } \\
\text { Season }\end{array}$ \\
\hline
\end{tabular}

** Similar letters in one column means no significant differences

Figure.1

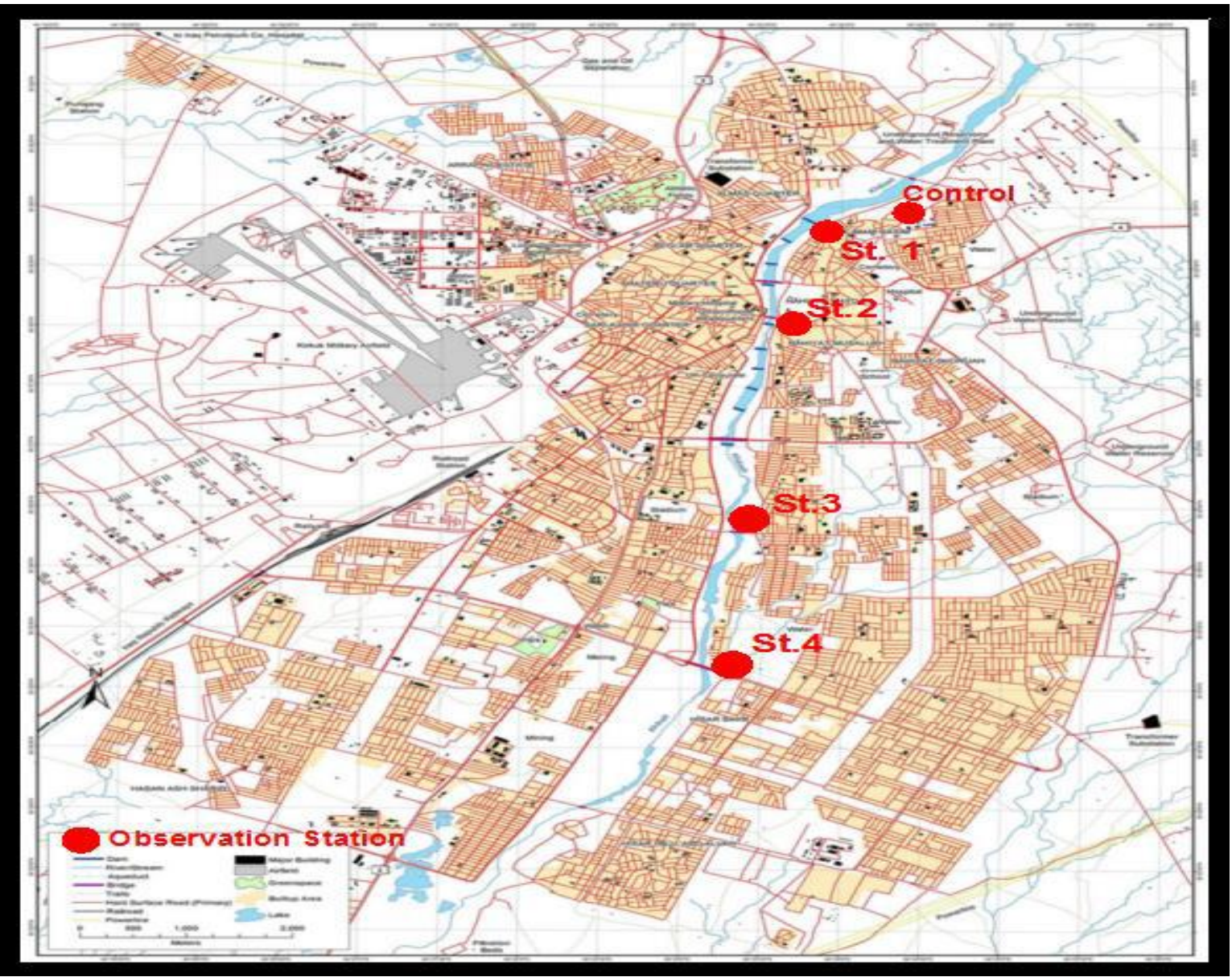


Table 2 shows the racial concentration of cadmium and copper in the part-shoot and root of the plant baker was measured cadmium concentration in parts of the plant and there are varying amounts in different parts of the plant parts and increase the concentration of cadmium as increasing amounts raised from heavy elements and results approach from the results of several studies on the measure heavy water elements, including (Hassan Oghli, 2002; Jabraeel et al., 2015; Yasin et al., 2007) and was a concentration of heavy metals in the water at contaminated sites is not within the Iraqi and international standards, while the site control was within the standards, where the copper concentration in the root baker plant in the spring, the highest concentration of the element copper in the root of the baker in the first position $(0.76 \mathrm{mg} / \mathrm{kg})$ and the lowest concentration in the fourth site $(0.1 \mathrm{mg} / \mathrm{kg})$, while in the vegetative part of the highest concentration $(1.4 \mathrm{mg} / \mathrm{kg})$ in the first position and the lowest concentration $(0.3 \mathrm{mg} / \mathrm{kg})$, while cadmium highest concentration in the root in the first position $(0.05 \mathrm{mg} / \mathrm{kg}$ ) and the lowest concentration in control $(0.0 \mathrm{mg} / \mathrm{kg})$ and the highest concentration in the vegetative portion $(0.04 \mathrm{mg} / \mathrm{kg}$ ) and non-existent in control.

\section{References}

Abbasi, M. 2013. Analysis of sewage in ElectricityDistribution Company of Alborz province, comparewith the standards and control solutions for sewagetreatment and optimum use of sewage the thirdinternational conference on environmental planning and management, Tehran University.

Alavi, V., Zaheryun, M., Moridi, A. 2012. Risk assessment of wastewater in irrigation, using models of AHP, the ninth International Congress of Civil Engineering, industrial University of Isfahan.

Al-Janabi, A.Y., Al-Saadi, N.A., Zainal, Y.M., Al-Bassam, K.S., Al-Delaimy, M.R. 1992. Work procedures of the S.E of Geological survey and mining. State Establishment of Geological survey and mining (geosurv.) part 21, No. 2002, B, pp. 59-65.

Balasubramanian, R., He, J., Wang, L.K. 2009. "Control, Management, and Treatment of Metal Emissions from Motor Vehicles". In Shammas, LK; Wang, JP; Chen, Y; et al. Heavy Metals in the Environment. CRC Press. pp. 475-490.

Bouriche, H., Meziti, H., Senator, A., Arnhold, J. 2011. "Antiinflammatory, free radicalscavenging, and metal-chelating activities of Malva parviflora.

Harden, G.J. (Ed) 2002. 'Flora of New South Wales.' (University of New South Wales Press Ltd: Sydney, Australia)

Hassan Oghli, A. 2002. The use of treated wastewater of treatment plants and domestic waste in agricultural irrigation and artificial recharge of groundwater aquifers. $\mathrm{PhD}$ thesis, College of Agriculture, Tehran.

Jabraeel, Parisa Nejad, Fataei, Ebrahim. 2015. Assessing the Environmental risk in using Wastewater of municipal sewage treatment plant in agricultural irrigation. Department of Environmental Sciences Ardabil Branch, Islamic Azad University Ardabil, Iran.

Reyahi Khoram, M., shariat, M., Azar, A., Moharamnejad, N., Mahjub, H. 2007. prioritizing the strategies andMethods of Treated Waste water Rusing by FuzzyAnalytic Hierarchy 
process, Int. J. Agri. Biol., 15608530/2007/09-2-319-323

Yasin, A., AL Zubi. 2007. Application of Multicriteria Analysis for Ranking and Evaluation of waste water treatment plants and its Impact on the Environment and public. Health case study from J., 3(2): 155-160.

\section{How to cite this article:}

Yasin M. Ahmed, Awaz B. Mahmood and Hiyam J. Ibrahim. Measuring the Accumulation of Copper and Cadmium in the Vegetative Parts of the Plant and the Root of Malva parviflora as a result of Irrigation with Sewage in City of Kirkuk. Int.J.Curr.Res.Aca.Rev.4(5): 149-154.

doi: http://dx.doi.org/10.20546/ijcrar.2016.405.014 